مقاله يخوهشى

مجله دانشعاه علوم يزشكى رفسنجان

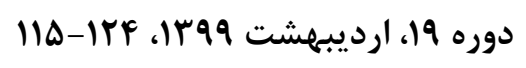

تأثير ائى كالو كاتجين_-r-كالات بر نقص حافظه كارى القاء شده با مورفين در

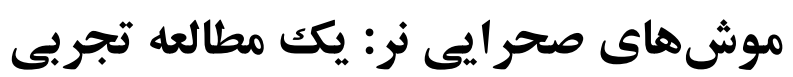

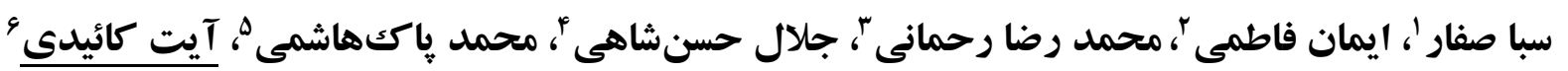

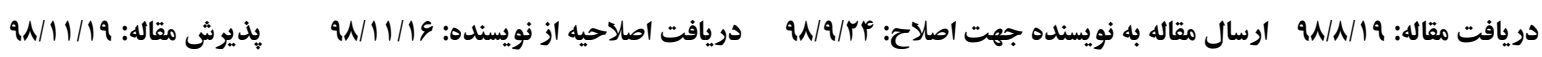
جكيده زمينه و هدف: مصرف مزمن مورفين، تغييرات ساختارى در بخشهاى مختلف مغز را به دنبال دارد. از طرفى ايى كالوكاتجين-

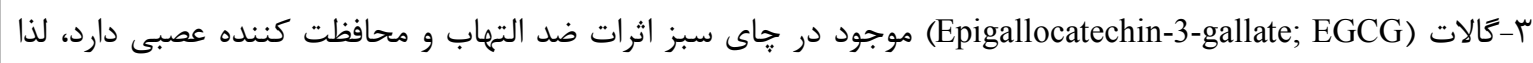

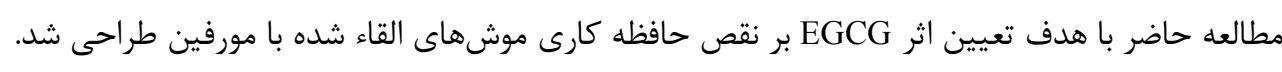

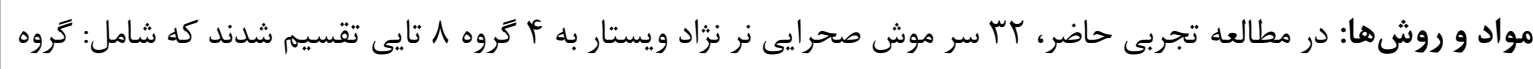

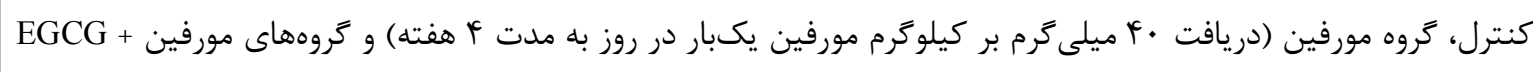

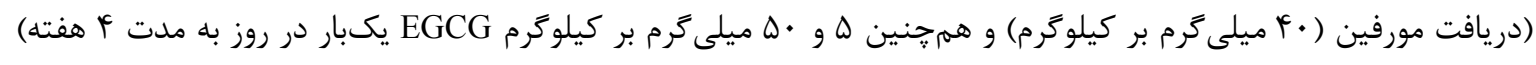

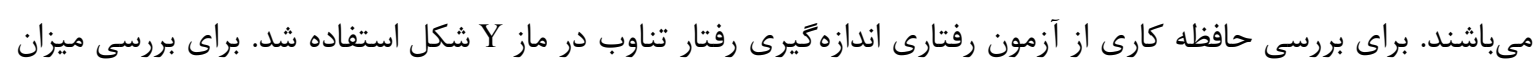

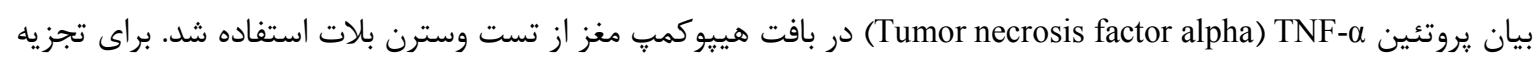

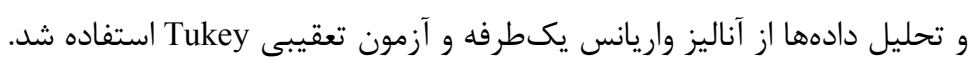

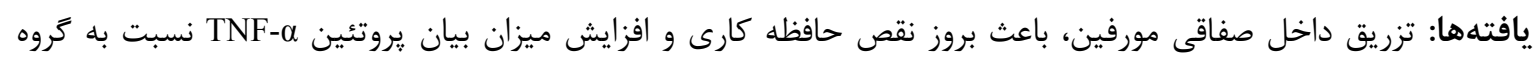

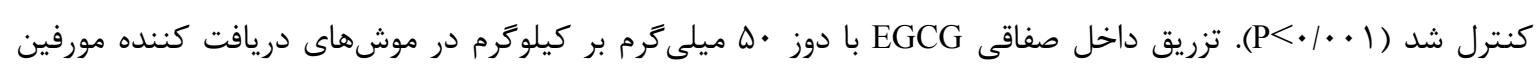

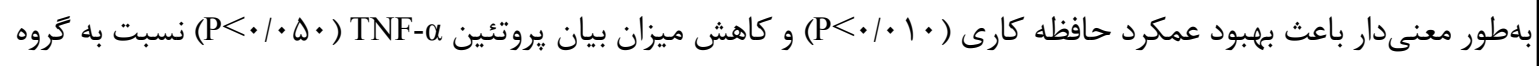
دريافت كننده مورفين شد.

نتيجه كيرى: EGCG مى تواند نقص حافظه كارى و التهاب عصبى القاء شده با مورفين را در موشهاى صحرايى بهبود بخشد.

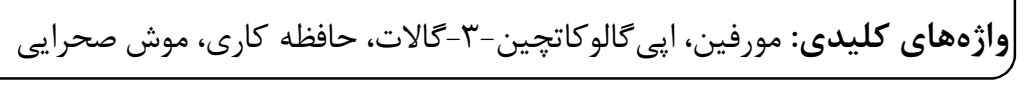

ا- دانشجوى كارشناسى ارشد فيزيولوزى، مركز تحقيقات فيزيولو زى - فارماكولوزى، يزوهشكده علوم پايه بزشكى، دانشخاه علوم بزشكى رفسنجان، رفسنجان، ايران

r- استاديار فارماكولوزى، مركز تحقيقات بيمارى هاى عفونى و گرمسيرى، دانشخاه علوم بزشكى كرمان، ايران

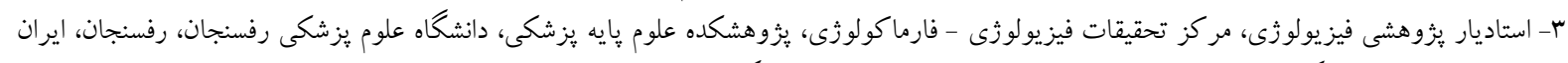

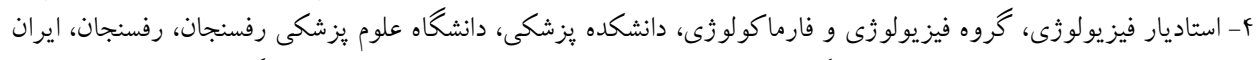

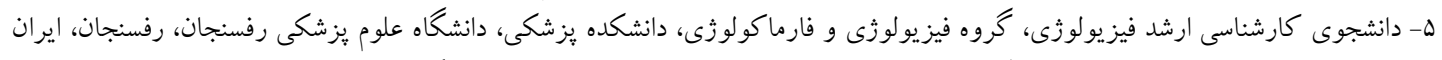

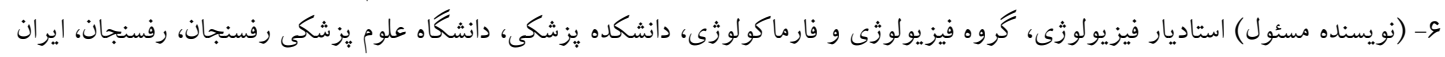

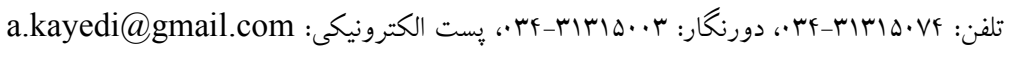




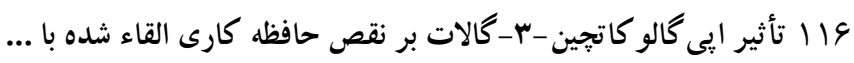

سلولى فاكتورهاى رشد نوروتروفيك مغز، در اعمال تنظيمى

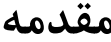
آنها بر عملكرد نورونها مداخله مى كند [F]. همرجنين مشاهده شده است كه استفاده مزمن از مورفين موجب القاء استرس اكسيداتيو، التهاب و بروز آيويتوز در نورونهاى مغز، بلويزه نورونهاى هييوكمب حيوانات آزمايشكاهى مىشود [ه-ه]]. فاكتور نكروز تومور آلفا ( Tumor necrosis factor (alpha; TNF- يكى از مههمترين واسطهها در ايجاد التهاب و يكى از سيتوكينهاى در كير در ايجاد واكنش فاز حاد در بدن انسان است و مصرف مورفين مىتواند باعث افزايش سطح بيان آن در بدن شود [V]] يلىفنولها تركيبات آنتىاكسيدانى طبيعى هستند كه قادرند راديكالهاى آزاد را جذب نموده و از بدن در برابر بسيارى از بيمارىها محافظت كنند. بهعنوان مثال يلىفنولها مىتوانند از بافتهاى بدن در برابر استرسهاى اكسيداتيو، افزايش لييويروتئين با هكالى هايين (Low-density lipoprotein; LDL) يرستات، سينه و يوست) جلوكيرى كنند [.•-1]. إيى كالوكاتجين گالات (Epigallocatechin gallate; EGCG)، مهمترين تر كيب يلىفنولى برى حاى سبز است كه از جمله مهمترين كروه از آنتىاكسيدانهاى طبيعى است و بسيار از خواص آنتىاكسيدانى קاى سبز به آن نسبت داده مىشود [ [ - -11]. با توجه به مطالب ذكر شده، از آنجايى كه مصرف مزمن مورفين مىتواند باعث ايجاد تغييرات ساختارى در بخشهاى مختلف مغز از جمله هييوكمب شود و باعث اختلال در حافظه كارى شود و از طرفى EGCG موجود در خاى سبز داراى اثرات محافظت نورونى مىباشد، بنابراين مطالعه حاضر با هدف تعيين اثر احتمالى EGCG سطح TNF-

مورفين داروى ارزشمندى است كه عمدتاً از آن براى تسكين دردهاى حاد و شديد كلينيكى استفاده مىشود. مورفين علاوه بر اثرات ضد دردى شناخته شده، در فرآيندهاى تكوين مغز، عصب زايى، تمايز سلولى و آيويتوز نورونهاى سيستم عصبى مركزى نيز تأثير كذار مىباشد. استفاده مزمن از مورفين و ساير اوييوئيدها باعث ايجاد وابستكى و تحمل (Tolerance) است كه وابستگى مزمن به مورفين سبب بروز اختلالات شناختى از جمله بروز نقايص حافظه و يادَيرى مىشود. علاوه بر اين مورفين باعث بروز استرس اكسيداتيو، مرك نورونى، بروز التهاب، تغيير در مسيرهاى پيامرسانى درون سلولى و فاكتورهاى نوروتروفيك، مانند فاكتور رشد عصبى مشتق از مغز مىشود [T]. با توجه به اينكه كيرندهاى اوييوئيدى در بافت مغز به وفور بيان مىشوند (بهويزه نواحى قشر يره فورنتال، هييوكمب، هسته لوكوسرئولوس، هسته اكومبنس) و هم:جنين مسيرهاى عصبى آوران از ساير نقاط مغز به اين نواحى نيز حاوى نوروييتيدهاى اوييوئيدى هستند، نشان داده شده است كه اين كيرندهها باعث تغييراتى در انواع يادكيرى و حافظه مى گردند. هم:جنين مطالعات كذشته نشان دادهاند كه مورفين با شكليذيرى نامطلوب و آتروفى دندريتى يا تخريب نورونى در هييوكمب و ساختمانهاى وابسته به قشر ليمبيك باعث كاهش ميزان نورون زايى در لايهى سلولهاى كرانولى هييوكامب موشهاى بالغ مى كردد [ـ]. مورفين هم جنين از طريق تداخل با مسيرهاى مربوط به پيامرسانى درون 


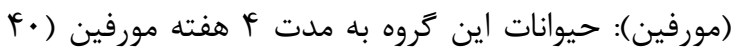

ميلى گرم بر كيلوگرم يك بار در روز، بلصورت زير يوستى) را دريافت كردند. گروه سوم (مورفين + ه ميلى گرم بر كيلوگرم EGCG گرم بر كيلوگرم مورفين را بهصورت زير يوستى و همرجنين ه ميلى گرم بر كيلوگرم EGCG را به صورت داخل صفاقى دريافت كردند. گروه جهارم (مورفين + •• ميلى كيلوگرم EGCG): حيوانات اين گروه روزانه به مدت ع هفته r. ميلى Fرم بر كيلوكرم مورفين را بهصورت زير يوستى و همجنين · له ميلى گرم بر كيلوگرم EGCG را به صورت داخل

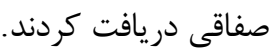
در يايان دوره \& هفته اى تيمار با مورفين و EGCG ، براى بررسى حافظه كارى از تست رفتارى اندازه حيرى رفتار تناوب در ماز Y-maze spontaneous alternation test) شكل Y) استفاده شد. دادههاى آزمون ماز Y- شكل مىتواند نشان دهنده شاخصى از حافظه فضايى كارى در كوتاه مدت (از نوع بازشناختى) در جوند گانى نظير موش كوجى آزمايشگاهى و همجنين موش صحرايى باشد. در اين آزمون ميزان عملكرد حيوانات از نظر حافظه كارى با مشاهده بررسى رفتار مداوم خودمختار حيوان در يك روز مورد بررسى قرار گرفت. ماز مربوط به اين آزمون داراى ؟ بازو از جنس يلكسى گلاس بود. هريك از بازوها داراى ابعاد ها× • • • • سانتىمتر بوده و بازوها از طريق يك محوطه مركزى به هم متصل بودند. براى انجام آزمون هر موش صحرايى در قسمت انتهايى يك بازو قرار داده مىشد و امكان دسترسى آزاد آن به تمام نواحى ماز در يك دوره زمانى 1 دقيقهاى فراهم مى گرديد. با مشاهده رفتار
(به عنوان يك شاخص التهابى) و نقص حافظه كارى موشهاى القاء شده با مورفين طراحى شده است. اميد است كه نتايج اين مطالعه بتواند در آينده در بيماران مبتلا به مصرف مورفين مؤثر واقع شود.

\section{مواد و روشها}

اين مطالعه تجربى در سال Vqr ا انجام شد. از r موش

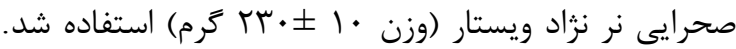
موشها به صورت تصادفى در جهار گروه در قفسهاى يلاستيكى در يك جرخه با ساعته روشنايى / تاريك (روشنايى از ساعت · ·: • الى · ·: 19) با دسترسى آزاد به غذا و آب نكهدارى و در دماى r土س درجه سانتى رطوبت •-A· درصد نتخدارى مىشدند. تمام مراحل آزمايشى مطابق دستورالعمل مراقبت و استفاده از حيوانات آزمايشَاهى در دانشگاه علوم يزشكى رفسنجان انجام شد. همجزنين اين مطالعه داراى كد اخلاق از دانشگاه علوم يزشكى IR.RUMS.REC.1396.210 رفنجان به شماره ثبتى مىباشد. در اين مطالعه، از هر موش فقط يكبار استفاده شد. EGCG از سرنگ انسولين بهصورت داخل صفاقى و همرجنين مورفين نيز به صورت زير يوستى تزريق مىشد. كروههاى آزمايشى و نحوه تيمار: هر گروه آزمايشى شامل 1 حيوان بود. در اين مطالعه حيوانات به جهار گَروه آزمايشى تقسيم شدند: گروه اول دريافت كننده سالين (كنترل): حيوانات به مدت f هفته، سالين (به عنوان حلال EGCG) را دريافت كردند. گروه دوم 


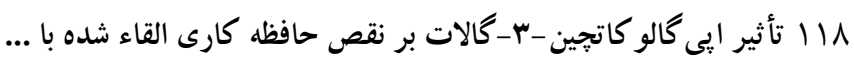

به مدت له دقيقه در محلول TBS-T ، غشاء به مدت 1 ساعت با آنتىبادى ثانويه متصل به HRP به انكوبه شد. در نهايت غشاء در معرض محلول (peroxidase سوبستراى ECL (chemiluminescence) Eرار كرفته و باندهاى حاصل بر روى فيلم راديولوزى مخصوص ثبت شدند. جهت كمى كردن بيان يروتئينهاى TNF- يا نرم افزار ImageJ نسخه Iاه/ استفاده شد [r]. با توجه به اينكه دادهها به صورت كمى بود، توسط آزمون فرض نرمال بودن دادهها تأييد كرديد Shapiro-Wilk

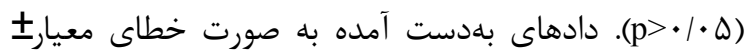
ميانگين بيان شدند و براى مقايسه اختلاف بين گروهها از آزمون آناليز واريانس يكطرفه و يس آزمون Tukey استفاده شد. سطح معنى دارى در آزمونها هـ • • در نظر گرفته شد.

نتايج

نتايج اين مطالعه نشان داد تيمار مزمن حيوانات با مورفين باعث كاهش درصد رفتار تناوبى در ماز Y-شكل نسبت به گروه سالين مىشود (1 (P<). علاوه بر اين، نتايج اين مطالعه نشان داد كه تجويز همزمان EGCG ( • ه ميلى گرم بر كيلوگرم) به حيوانات تيمار شده با مورفين شده باعث بهبود

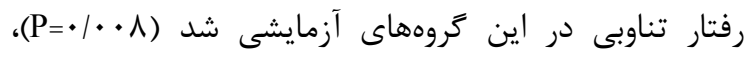
بهصورتى كه تفاوت معنى دارى ميان اين گروه با گروه سالين مشاهده نشد (ه •|•PCG) لازم به ذكر است كه تجويز EGCG با دوز ه ميلى حيوانات وابسته به مورفين نداشت و در يايان همرجنان ميان
حيوان در طى اين مدت، تعداد دفعات ورود حيوان به داخل هر بازو ثبت مىشد. معيار ورود حيوان به داخل يك بازو با ورود قاعده دم حيوان بطور كامل در داخل بازو در نظر كرفته شد، رفتار تناوب به عنوان ورودهاى موفق و رشت سر هم به داخل تمام بازوها در مجموعههاى سه تايى در نظر كرفته شد. درصد تناوب از نسبت تناوب مشاهده شده به حداكثر تناوب (r- تعداد كل بازوهاى وارد شده ) × · · (محاسبه شد [با]. يس از اتمام ماز Y-شكل، حيوانات تحت بيهوشى عميق با استفاده از تزريق داخل صفاقى كتامين ( •ه ميلى كرم بر كيلو كرم)، كشته شده و مغز آنها از جمجمه به سرعت جدا سازى شد. بافت هييوكمب از ساير نواحى مغز جدا و بافت هييو كمب 1mM EDTA, 10mM Tris-HCl, ,0.1\% SDS, ) در بافر RIPA (0.1\% Na deoxycholate, 1\% NP-40 نمونه هموزن شده سانتريفيوز ( ( أ دور بر دقيقه، در دماى F درجه و به مدت • r دقيقه) و قسمت رويى كه حاوى نمونههاى يروتئين تام بافت بود، از آن استخراج و بر اساس روش برادفورد (Bradford) ميزان يروتئين هر نمونه

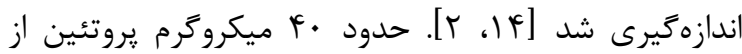
عصاره يروتئينى بر روى زل SDS-PAGE با غلظت درصد الكتروفورزر شد. سيّ نمونههاى الكتروفورز شده به غشاى Polyvinylidene Fluoride) PVDF) منتقل شده و به مدت يك شب در دماى ع درجه در محلول ه درصد TBS-T ( $\mathrm{NaCl} / 150 \mathrm{mM}$, Tris- $\mathrm{HCl} / 20 \mathrm{mM}$, and $0.1 \%$ Tween20; انكوبه شد. در مرحله بعدى غشاى PH7.4) آنتىبادى اوليه عليه TNF- يا T-actin داخلى) به مدت r ساعت انكوبه گرديد. يس از ب بار شستشو 
دوز •ه ميلى

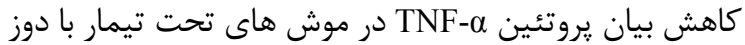
• له ميلى گرم بر كيلوگرم EGCG در مقايسه با حيوانات تيمار شده با مورفين به تنهايى شده بود (ه •/P<). هر جند تفاوت معنى دارى در بيان يروتئين TNF- بين گروه تيمار شده با مورفين به تنهايى و گروه تيمار شده با مورفين و ه ميلى بر كيلوگرم پلى فنول EGCG مشاهده نشد (ه •/•).
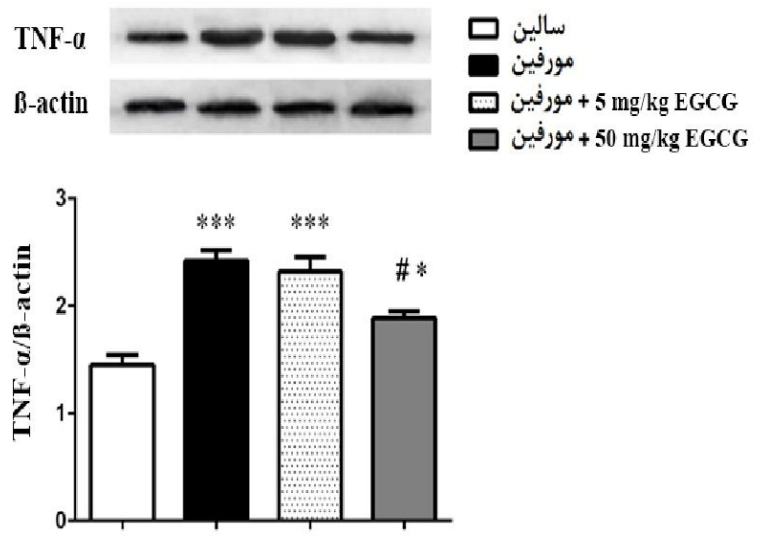

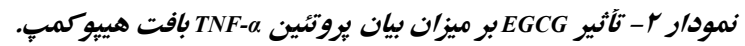
دادهها بهصورت خطاى معياري ميانكين نشان داده شلده اند. تعلداد

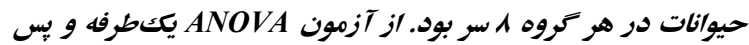

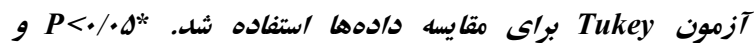

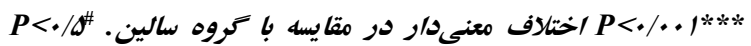
اختلاف معنىی/ر در مقا يسه بإكروه مورفين.

بحث مطالعه حاضر با هدف تعيين اثر EGCG بر حافظه كارى موشهاى تيمار شده با مورفين انجام شد. يافتههاى مطالعه حاضر نشان داد كه تيمار با مورفين منجر به ايجاد اختلال در حافظه كارى و افزايش التهاب در بافت هييوكمٍ موش هاى صحرايى مىشود. از سوى ديگر EGCG باعث بهبود حافظه
اين گروه با گروه كنترل/سالين تفاوت معنى دارى وجود داشت

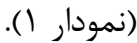

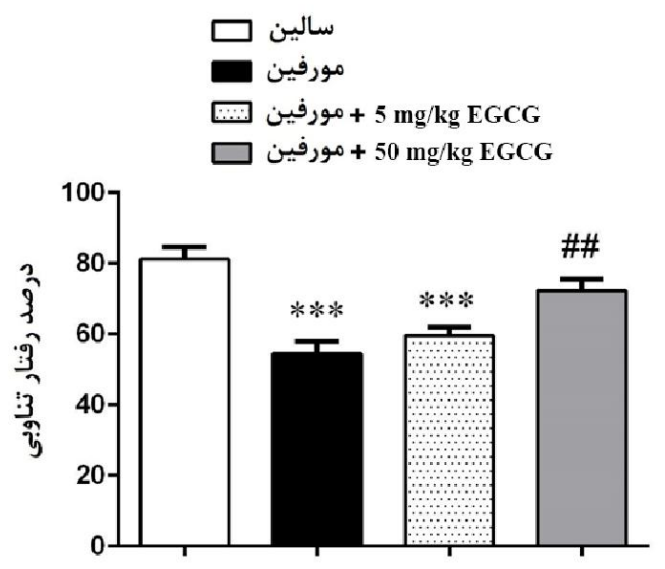

نمودار | - تأثير مورفين و EGCG بر ميزان درصد رفتار تناوبى در ماز

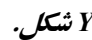

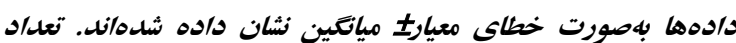

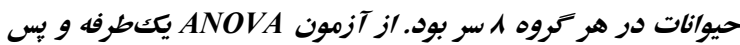

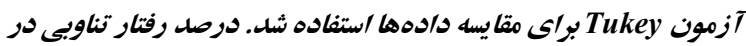

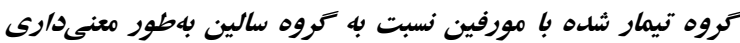

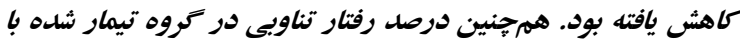
EGCG

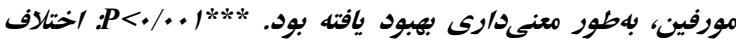

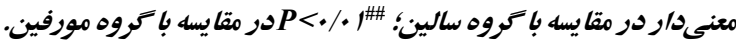
ميزان بروز التهاب به دنبال تيمار مزمن با مورفين از طريقي اندازهيرى ميزان بيان TNFيكى از مهمترين سايتوكاينهاى پيش التهابى مى TNF- $\alpha$ باشد كه مىتواند منجر به بروز تخريب و مرگ سلولى شود. بنابراين در اين مطالعه بهصورت غير مستقيم با اندازهگيرى

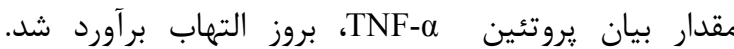
همان گونه كه در نمودار r نشان داده شده است، تيمار مزمن با مورفين باعث افزايش معنىدار بيان ثروتئين TNFبافت هييوكمٍ موشهاى صحرايى تيمار با مورفين نسبت به كروه كنترل شد (1 + P<). همجهنين تجويز EGCG (در 
• rا تأثير إيى كالو كاتجين -r-كالات بر نقص حافظه كارى القاء شده با ...

هيدروكسيل باعث تأثير در بسيارى از يارامترهاى مهم عملكردى، مانند سياليت، نفوذيذيرى، يتانسيل الكتريكى و انتقال كنترل شده متابوليتها در عرض غشاء مى گردد [ع []. لازم به يادآورى است كه مصرف مزمن مواد مخدر از جمله مورفين با افزايش قابل توجه يراكسيداسيون ليييدى در ارتباط است [ץ]. در مطالعه حاضر در بررسى حافظه كارى با استفاده از آزمون ماز Yنان داده شد كه تعداد كل ورودىها و درصد رفتار تناوبى در تروههاى تحت درمان با EGCG بيشتر از ساير گروههاى دريافت كننده مورفين بود كه نشان دهنده اثرات محافظت كننده سيستم عصبى مىباشد. EGCG مى تواند يادكيرى و حافظه فضايى را در مدلهاى حيوانى افزايش دهد. در اين رابطه، Renno و همكاران نشان دادند كه تركيب ״لى فنول EGCG جاى سبز با خواص آنتىاكسيدانى و ضد التهابى خود مى تواند در بهبود آسيب عصب سياتيك موشهاى صحرايى مؤثر باشد. آنان نشان دادند كه تجويز EGCG سرم مىشود. علاوه بر اين ميزان فاكتور التهابى اينترلوكينצ سرمى نيز در حيوانات تيمار شده با EGCG كاهش يافته بود [IV] همرجنين مشخص شده است كه EGCG باعث بهبود نقص حافظه، كوجكتر شدن وسعت ناحيه آسيب ديده در اثر سكته و همجنين بهبود يتانسيل پس سينايسى تقويت شده نورنهاى هييوكمٍ در موشهاى صحرايى مىشود [1 [ ] در اين رابطه He و همكاران در يك مطالعه نشان دادند كه يلى فنول EGCG جاى سبز مى تواند از نورونهاى كورتكس مغز موشهاى صحرايى در مقابل اثرات سمى آكريل
كارى و كاهش ميزان التهاب در هييوكمٍ مغز در اين حيوانات مىشود. مطالعات قبلى نشان داده اند كه حيوانات تحت درمان با مورفين داراى اختلال حافظه هستند. آر خه مكانيسمهايى كه اثرات مخرب مورفين بر حافظه را تحت تأثير قرار مىدهد هنوز كاملا شناخته نشدهاند، اما يِشنهاد شده است كه تجويز مورفين از طريق نقص در عملكرد هييوكمب و ساير نواحى مغز كه مرتبط با عملكرد حافظه مىباشند، تأثير مخرب خود را اعمال مى كند [r]. التهاب نورونى و اختلال عملكرد ميتوكندرى از جمله نشانَرهاى بيمارىهاى تخريب نورنى در سيستم عصبى مركزى مىباشند. هر دو عوامل التهاب نورونى و اختلال عملكرد ميتوكندرى، مىتوانند از طريق آزاد شدن بيش از اندازه كونههاى واكنشكر اكسيثنى و نيتروزنى منجر به افزايش استرس اكسيداتيو مخرب شوند. استرس اكسيداتيو حاصل نيز باعث افزايش تخريب نورونى و التهاب و در نتيجه پِيشبرد حلقه معيوب آسيب عصبى مىشود. سايتوكاين TNFمىباشد كه از طريق كيرنده TNFنقش مهمى را در يیشرفت التهاب ايفاء مى كند. علاوه بر اين از طريق عمل بر كيرنده TNFكردن آنزيم هاى توليد كننده كونههاى واكنش نيتروزنى بروز استرس اكسيداتيو را بيش از پيش القاء نمايد [ [ ] ]. توليد بيش از حد راديكال آزاد در شرايط خاص مىتواند سبب القاء جندين اثر مختلف شامل تغييرات و شكست در سطح مولكولهاى تشكيل دهنده ساختمان سلولى شود. يراكسيداسيون اسيدهاى خرب غير اشباع توسط راديكال 
همزمان EGCG موجب كاهش اثرات زيانبار رزيم غذايى يرجرب بر حافظه فضايى در موشهاى تغذيه شده با رزيم

$$
\text { نتيجرب شد [اب]. }
$$

داد هاى بلدست آمده از اين مطالعه نشان داد كه تجويز EGCG به موشهاى صحرايى مى تواند از القاء نقص حافظه كارى در آنها جلوگيرى كند. با توجه به دادهاى حاصل از اين تحقيق، اثر مفيد EGCG بر حافظه كارى در مطالعه حاضر مىتواند تاحدودى ناشى از كاهش التهاب در مغز موشهاى صحرايى تيمار شده با مورفين باشد.

$$
\text { تشكر و قدردانى }
$$

اين مطالعه با حمايت مالى دانشخاه علوم يزشكى رفسنجان و از محل طرح شماره 9\&|V| انجام شده است. نويسندFان مراتب

$$
\text { قدردانى خود را اعلام مىنمايند. }
$$

آميد محافظت كند. آنان نشان دادند تجويز EGCG باعث كاهش استرس اكسيداتيو و همجنين كاهش آيويتوز در نورنهاى كورتكس موشهاى صحرايى تيمار شده با آكريل آميد مىشود [9 1 ]. از جمله در ديخر مطالعات Yuو همكاران نشان دادند كه يلى فنول EGCG موجود در جاى سبز با مهار استرس اكسيداتيو از بروز التهاب و آيوپتوز ناشى از آرسنيك در موشهاى آزمايشى جلوگيرى مى كند. دادههاى آزمايشات آنان نشان داد كه كه تجويز EGCG به همراه آرسنيك موجب كاهش سطح فاكتورهاى التهابى اينترلوكين-4 و TNFa خون، كاهش سطح استرس اكسيداتيو و آيويتوز در بافتهاى طحال و تيموس شده بود [ ·r]. Mi و همكاران نيز نشان دادند كه پيلى فنول EGCG موجود در جاى سبز مىتواند از نقص حافظه القاء شده با رزيم غذايى گرجرب در موشهاى آزمايشَاهى جلوكيرى كند. دادهاى آنان نشان داد كه تجويز

\section{References}

[1] Zhang Y, Loh HH, Law P-Y. Effect of opioid on adult hippocampal neurogenesis. The Scientific World Journal 2016; 2016.

[2] Shibani F, Sahamsizadeh A, Fatemi I, Allahtavakoli M, Hasanshahi J, Rahmani M, et al. Effect of oleuropein on morphine-induced hippocampus neurotoxicity and memory impairments in rats. Naunyn-Schmiedeberg's Archives of Pharmacology 2019; 1-9.
[3] Grilli M. Chronic pain and adult hippocampal neurogenesis: translational implications from preclinical studies. Journal of Pain Research 2017; 10: 2281.

[4] Nestler EJ, Lüscher C. The molecular basis of drug addiction: linking epigenetic to synaptic and circuit mechanisms. Neuron 2019; 102(1): 48-59. 
[5] Pan J, He L, Li X, Li M, Zhang X, Venesky J, et al. Activating autophagy in hippocampal cells alleviates the morphine-induced memory impairment. Molecular Neurobiology 2017; 54(3): 1710-24.

[6] Shibani F, Sahamsizadeh A, Fatemi I, Allahtavakoli M, Hasanshahi J, Rahmani M, et al. Effect of oleuropein on morphine-induced hippocampus neurotoxicity and memory impairments in rats. Naunyn-Schmiedeberg's Archives of Pharmacology 2019; 392(11): 1383-91.

[7] Eidson LN, Inoue K, Young LJ, Tansey MG, Murphy AZ. Toll-like receptor 4 mediates morphine-induced neuroinflammation and tolerance via soluble tumor necrosis factor signaling. Neuropsychopharmacology 2017; 42(3): 661 .

[8] Zhang H, Tsao R. Dietary polyphenols, oxidative stress and antioxidant and anti-inflammatory effects. Current Opinion in Food Science 2016; 8: 33-42.

[9] Mileo AM, Miccadei S. Polyphenols as modulator of oxidative stress in cancer disease: new therapeutic strategies. Oxidative Medicine and Cellular Longevity $2016 ; 2016$.

[10] Lall RK, Syed DN, Adhami VM, Khan MI, Mukhtar H. Dietary polyphenols in prevention and treatment of prostate cancer. International Journal of Molecular Sciences 2015; 16(2): 3350-76.
[11] de Oliveira MR, Nabavi SF, Daglia M, Rastrelli L, Nabavi SM. Epigallocatechin gallate and mitochondria - a story of life and death. Pharmacological research 2016; 104: 70-85.

[12] Chowdhury A, Sarkar J, Chakraborti T, Pramanik PK, Chakraborti S. Protective role of epigallocatechin-3gallate in health and disease: a perspective. Biomedicine \& Pharmacotherapy 2016; 78: 50-9.

[13] Mozafari N, Moghadam-Ahmadi A, Shamsizadeh A, Fatemi I, Allahtavakoli M, Kaeidi A. The effect of ampakine Farampator (CX691) on working memory in a rat model of Alzheimer's disease induced by Amyloid beta 1-42. Iranian Journal of Physiology and Pharmacology 2018; 2(2): 107-0.

[14] Bradford MM. A rapid and sensitive method for the quantitation of microgram quantities of protein utilizing the principle of protein-dye binding. Analytical Biochemistry 1976; 72(1-2): 248-54.

[15] Fischer R, Maier O. Interrelation of oxidative stress and inflammation in neurodegenerative disease: role of TNF. Oxidative Medicine and Cellular Longevity $2015 ; 2015$.

[16] Motaghinejad M, Karimian M, Motaghinejad O, Shabab B, Yazdani I, Fatima S. Protective effects of various dosage of Curcumin against morphine induced 
apoptosis and oxidative stress in rat isolated hippocampus. Pharmacological Reports 2015; 67(2): 230-5.

[17] Renno WM, Benov L, Khan KM. Possible role of antioxidative capacity of (-)-epigallocatechin-3gallate treatment in morphological and neurobehavioral recovery after sciatic nerve crush injury. Journal of Neurosurgery: Spine 2017; 27(5): 593-613.

[18] Ding J, Fu G, Zhao Y, Cheng Z, Chen Y, Zhao B, et al. EGCG ameliorates the suppression of long-term potentiation induced by ischemia at the Schaffer collateral-CA1 synapse in the rat. Cellular and molecular neurobiology 2012; 32(2): 267-77.
[19] He Y, Tan D, Bai B, Wu Z, Ji S. Epigallocatechin-3gallate attenuates acrylamide-induced apoptosis and astrogliosis in rat cerebral cortex. Toxicology Mechanisms and Methods 2017; 27(4): 298-306.

[20] Yu N-H, Pei H, Huang Y-P, Li Y-F. (-)Epigallocatechin-3-Gallate inhibits arsenic-induced inflammation and apoptosis through suppression of oxidative stress in mice. Cellular Physiology and Biochemistry 2017; 41(5): 1788-800.

[21] Mi Y, Qi G, Fan R, Qiao Q, Sun Y, Gao Y, et al. EGCG ameliorates high-fat-and high-fructose-induced cognitive defects by regulating the IRS/AKT and ERK/CREB/BDNF signaling pathways in the CNS. The FASEB Journal 2017; 31(11): 4998-5011. 
Fץ

\title{
The Effect of Epigallocatechin gallate on Morphine Induced Working Memory Defects in Rats: An Experimental Study
}

\author{
S. Saffar ${ }^{1}$, I. Fatemi ${ }^{2}$, M. R. Rahmani ${ }^{3}$, J. Hassanshahi ${ }^{4}$, M. Pak-Hashemi ${ }^{5}, \underline{\text { A. Kaeidi }}^{6}$ \\ Received: 10/11/2019 Sent for Revision: 15/12/2019 Received Revised Manuscript: 05/02/2020 Accepted: 08/02/2020
}

Background and Objectives: Chronic morphine use leads to structural changes in the brain. Some studies have shown the antioxidant and neuroprotective effects of Epigallocatechin gallate (EGCG) as a main polyphenol of green tea. Therefore, the aim of this study was to investigate the effect of EGCG on working memory in morphine-treated rats. Materials and Methods: In this experimental study, 32 male Wistar rats were divided into 4 experimental groups (8 rats in each group): 1- control; 2- Morphine group (the animals received $40 \mathrm{mg} / \mathrm{kg}$ morphine for 4 weeks, once a day, s.c.); 3 and 4- Morphine + EGCG, the animals received morphine (40 mg/kg, 4 weeks, once a day, s.c.) and EGCG (5 and $50 \mathrm{mg} / \mathrm{kg}$, once a day, i.p.). To evaluate the working memory, Y-maze spontaneous alternation was used. To measure the level of TNF- $\alpha$ protein expression in brain hippocampus tissue, the western blot test was used. One-way ANOVA with Tukey's post hoc test was used for data analysis.

Results: Intraperitoneal morphine injection resulted in working memory deficits and increased TNF- $\alpha$ protein expression levels compared to the control group $(\mathrm{p}<0.001)$. Moreover, intraperitoneal injection of $50 \mathrm{mg} / \mathrm{kg}$ EGCG in morphine treated rats significantly improved working memory $(\mathrm{p}<0.01)$ and decreased TNF- $\alpha$ protein expression level $(\mathrm{p}<0.05)$ compared to solely morphine treated group.

Conclusion: EGCG improved morphine induced working memory deficits in rats.

Key words: Morphine, EGCG, Working memory, Rat

Funding: This research was funded by Rafsanjan University of Medical Sciences.

Conflict of interest: None declared.

Ethical approval: The Ethics Committee of Rafsanjan University of Medical Sciences approved the study (IR.RUMS.REC.1396.210).

How to cite this article: Saffar S, Fatemi I, Rahmani M R, Hassanshahi J, Pak-Hashemi M, Kaeidi A. The Effect of Epigallocatechin gallate on Morphine Induced Working Memory Defects in Rats: An Experimental Study. J Rafsanjan Univ Med Sci 2020; 19 (2): 115-24. [Farsi]

\footnotetext{
1- MSc Student of Physiology, Physiology-Pharmacology Research Center, Research Institute of Basic Medical Sciences, Rafsanjan University of Medical Sciences, Rafsanjan, Iran, ORCID:321x-6912-0001-0000

2- Assistant Prof. of Pharmacology, Research Center of Tropical and Infectious Diseases, Kerman University of Medical Sciences, Kerman,

Iran, ORCID: 0000-0002-9666-9651

3- Research Assistant Prof. of Physiology, Physiology-Pharmacology Research Center, Research Institute of Basic Medical Sciences, Rafsanjan University of Medical Sciences, Rafsanjan, Iran, ORCID: 0000-0001-7395-5770

4 Assistant Prof. of Physiology, Dept. of Physiology and Pharmacology, Medical School, Rafsanjan University of Medical Sciences, Rafsanjan, Iran, ORCID: 0000-0003-3754-8152

5-MSc Student of Physiology, Dept. of Physiology and Pharmacology, Medical School, Rafsanjan University of Medical Sciences, Rafsanjan, Iran, ORCID:0000-0002-1645-6980

6-Assistant Prof. of Physiology, Dept. of Physiology and Pharmacology, Medical School, Rafsanjan University of Medical Sciences, Rafsanjan, Iran, ORCID: 0000-0002-3292-2603

(Corresponding Author) Tel: (034) 31315074, Fax: (034) 31315003, E-mail: a.kayedi@gmail.com

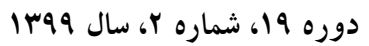
مجله دانشكاه علوم يزشكى رفسنجان
} 